УДК 338.23

Polbitsyn S.N.
Ural Federal University
named after the first President of Russia B.N. Yeltsin,
Institute of Economy
UrO RAN
Ekaterinburg, Russia
Abidullah ${ }^{2}$
Ural Federal University
named after the first President of Russia B.N. Yeltsin,
Ekaterinburg, Russia

\title{
RUSSIAN UNIVERSITY STUDENTS INTENTIONS TOWARDS SOCIAL ENTREPRENEURSHIP
}

\begin{abstract}
Social entrepreneurship is nowadays an appealing topic for researchers to investigate. It is considered to be an agent for social and economic development. To involve youth in social entrepreneurship and provide them with the opportunity to use their knowledge, skills and abilities to solve real world problems is a task to be addressed by modern society. This paper explains Russian university students' intention towards social entrepreneurship which is considered to be the predictor of actual behavior. We developed hypothesizes based on factors which have an impact on the social entrepreneurial intention. The tested hypothesizes confirm that attitude as well as subjective norm and perceived behavioral control all have a positive impact on the social entrepreneurial intention. The entrepreneurial environment and education as a contextual element were found to be significant predictors of the social entrepreneurial intention. The study uses the quantitative method where data of 107 Russian students were collected and analyzed using Statistical Package for Social Sciences (SPSS, version 20). In order to detect the impact of variables on each other, correlation and multiple regression tests were run. The results show positive intentions of Russian university students towards entrepreneurship. The study also found that contextual variables-entrepreneurial environment and education have an impact on social entrepreneurship intention. The entrepreneurial environment was found to be the most significant amongst other variables of attitude, subjective norms and perceived behavioral control.
\end{abstract}

Key words: attitude toward entrepreneurship; perceived behavioral control; subjective norm; entrepreneurial intention; entrepreneurship environment and education.

\section{Introduction}

The environment is changing day by day due to rapid innovation. The needs, wants and demands of humans are also increasing rapidly. The fulfilment of these human needs, wants and demands are possible from the surrounding. There is a need to come out with a workable strategy and do things in innovative and proactive ways. The young generation can play a vital role here to utilize their innovative skills and find the solution of real world problems. They have abilities, but the lack of guidance and skills in order to focus on solving real world problems. Universities are places in which these skills of the students can be polished, developed as well as put them in the proper direction. Most graduates today face the greatest challenges of the present market condition either through employment seeking or entrepreneurship [1]. 
The concept of social entrepreneurship is attracting a lot of attention from researchers and policy makers. Now It is not only limited to organizations sessions of discussions but also become part of the curriculum in various business schools [2]. Entrepreneurship brings innovative changes in a country's development, prosperity and economy [3]. It is important to study the factors which are associated with entrepreneurs pointed out by researchers in the field in order to overcome the current social and economic challenges. The purpose of the study is to draw a portrait to policy makers and educators by involving youths in entrepreneurship. During the Soviet Union, the Russian economy was a planned economy where large production firms were owned by the state and it was difficult to run own firms.

Now the economic pattern, education policies and other entrepreneurial related factors are changing, which need to be investigated [4]. At a conference in Moscow called "Time for new opportunities 15-20' forum of entrepreneurs' director of the HSE Centre for social entrepreneurship and social innovation studies Alexandra Moskovskaya said, till 2007 a web search did not come up with any link on this topic in Russia [5]. This scenario explains that social entrepreneurship is a core topic to investigate in the case of Russia to find out the intention, and attitude towards social entrepreneurship, especially youth. This study explains the factors

\footnotetext{
${ }^{1}$ Polbitsyn Sergei Nikolaevich - Doctor of Economics, Professor, Department of Regional Economics, Innovative Business and Security Department, Ural Federal University named after the first President of Russia B.N. Yeltsin; Senior Researcher, Institute of Economy, the Urals' Chapter of RAS, Ekaterinburg, Russia (620002, Ekaterinburg, Mira street, 19); e-mail: s.n.polbitsyn@urfu.ru.

2 Abidullah - Post-Graduate Student, Department of Regional Economics, Innovative Business and Security Department, Ural Federal University named after the first President of Russia B.N. Yeltsin, Ekaterinburg, Russia (620002, Ekaterinburg, Mira street, 19); e-mail: aabidulla@urfu.ru.
}

affecting social entrepreneurial intention of the students in the Institute of Public Administration and Entrepreneurship at Ural Federal University, Russia, based on the theory of planned behavior. The purpose of using the theory of planned behavior was not to prove the theory on the basis of this study, but to prove the facts on the basis of the theory. A lot of researchers have suggested the theory of planned behavior as a good tool for measuring entrepreneurial intention.

\section{Literature Review}

Social entrepreneurship has a lot of definitions because of different motives to become a social entrepreneur which make it difficult to define. Therefore, social entrepreneurship cannot be defined as a specific term. Social entrepreneurs develop social enterprises not only for profit making but also think to give back to the society. One of the main benefits of social enterprises is that it globalizes the societal values and issues which are mostly ignored by business enterprises [6]. Social enterprises do not only solve social problems, but the products and services of social enterprises fulfill all the demands of consumers and society [7]. According to [8] the interaction of members of the society with social entrepreneurs explains that they inspire others to build society friendly enterprises. In addition [9] social entrepreneur is the innovative character of the initiative. In another place Hockert defines social entrepreneurship cited by [10] in their book of social entrepreneurship 'Social purpose business ventures are hybrid enterprises straddling the boundary between the for-profit business world and social mission-driven public and nonprofit organizations. Thus, they do not fit completely in either spare'. Furthermore, Thompson describes 'Social entrepreneurs are those individuals who create businesses to serve the people of society [11].

Entrepreneurship is a means to create empowerment through self-employment as 
opposed to been employed by someone. It is the willingness to be involved in entrepreneurial activities and be self-employed [2]. For personal freedom, entrepreneurship became very attractive nowadays for those who are in the process of their career selection choice [12]. To perform a specific task or action needs a certain state of mind, researchers called that intention which also has a connection with other factors. The focus of intention is a behavior response towards external stimulus or to plan it [13]. To become an entrepreneur as a voluntary and conscious action [14]. In entrepreneurship, intention is the initial step and should be considered in the first. The intention is not considered as an actual behavior, but that leads to actual behavior. This does not necessarily mean that someone has intention towards a specific behavior and he/ she will certainly perform [15]. To become an entrepreneur is sometimes a long-term process, therefore this research is focusing on intention of the students not the actual behaviors. Also, there are some other factors that may enhance the intentions. Hence this research also includes the educational environment as a factor that affects intentions.

The educational environment of the students' affect not only their character, but also their career choices. Interaction with different people in university and participation in different activities, training and courses may inspire them towards a specific career choice. A separate construct was developed to explain the impact of the university environment and education on entrepreneurship intention of the students. The previous studies show that including social entrepreneurship education in the curriculum is quite developed and new event [16]. To provide social entrepreneurship in the form of qualified education has been developing all around the world to produce an innovative workforce to solve the real-world problems [17]. As we consider entrepreneurship is not only connected with economic activities like sustainability or productivity, but it's also the process of overcoming another obstacle together [18]. Here we can say that entrepreneurship education is not only to start a social or commercial enterprise, but to be able to solve the obstacle which people are facing in the present and predicted future. In the year (2011) Brock and Kim conducted a study and described the importance as well as the interest of social entrepreneurship education. They further alluded that social entrepreneurship is not limited to business schools but rather on many non-business faculties, institutions and high school are offering social entrepreneurship programs [19].

This research use theory of planned behavior (TPB) simply because it has more empirical validation than any other entrepreneurship models. Some examples of the implication of this theory are students' entrepreneurial intention in Turkey $[3,20]$ also conducted a comparative study used this theory, [21] conducted another study in Africa. On the other hand, the list of examples of social entrepreneurial research on students include [22, 23] in Egypt, and [24] in India. Therefore, this research adopts (TBP) theory as a tool for measuring students' intention towards social entrepreneurship in the Institute of Public Administration and Entrepreneurship at Ural Federal University.

\section{Social entrepreneurship intentions and (TPB).}

According to the theory of Ajzen (1991) human behavior is planned and intentions predict this behavior. These intentions are predicted by the attitude towards that behavior, subjective norm and perceived behavioral control $[15,25]$. The theory suggests three independent determinants of intention. The first one is attitude which is a measure of the appraisal degree of a person's favorable or unfavorable attitude toward a certain behavior. The second one is the subjective norm which is considered to be the social pressure to perform a behavior. The third one is perceived 
behavioral control which refers to the perceived ease or difficulty of performing a certain behavior. These three determinants directing to central constructs of the theory which is the intention of a person to perform certain behaviors. The intention to perform certain behaviors should be stronger with respect to favorable attitude, subjective norm and greater perceived behavioral control for that behavior. In this theory, intention is considered to be the reflection of the person's mental decision to perform or not to perform a certain behavior. In case of entrepreneurship [26] explains that intention is a state of mind which directs the actions and attention towards the achievement of specific goals of self-employment. To consider intention as a state of mind [27] has definitely an effort to perform entrepreneurial behavior and noticeable for those who want to become entrepreneurs.

According to the structure of the model theory of planned behavior there are three determinants which predict the intentions of students towards entrepreneurship. These determinants are attitude toward entrepreneurship, perceived behavioral control and subjective norm (TPB) are explained below.

The attitude towards entrepreneurship simply refers to the evaluation of ideas, event's objective or people to get selfpositive or negative reflection to that specific behavior. This importance of this factor in entrepreneurship has well explained in the study of [28]. Also, a lot of other researchers have found a positive association between attitude and entrepreneurial intention in their studies. In addition, the study of entrepreneurial intention in Turkey [3] found out that there is a relationship between attitude and entrepreneurship intentions.

The subjective norm as considered one of the main predictor which effect intention towards performing a certain behavior (TBP). In the case of entrepreneurship, the subjective norm is very important especially for young students because of the dilemma of approval or disapproval of certain behavior from their surroundings. In a comparative study of entrepreneurship intention among Scandinavia and USA students [20] found the positive

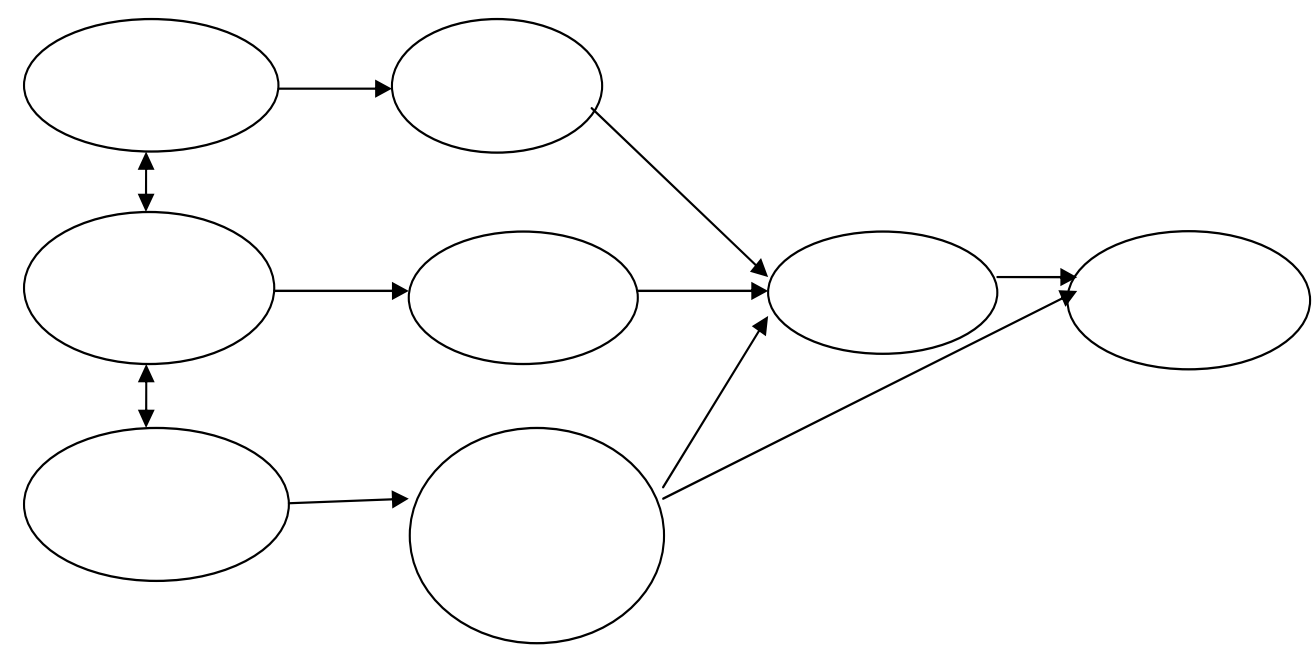

Figure 1. Theory of Planned Behavior 
contribution of this factor in students' intention towards entrepreneurship.

Perceived behavioral control suggests the perception of a certain task or behavior that it will be easy or difficult to accomplish. This construct explains the person's perception towards the resources, risk, effort, skills and knowledge to perform certain behavior. Many entrepreneurshipintentionstudieshaverevealed that this construct have a significant impact on students' intentions towards entrepreneurship. Therefore, perceived behavioral control is very important in making a decision about a career or performance of certain tasks. A study on students' intention towards entrepreneurship in Malaysia [29] detected a positive impact of perceived behavioral control on students' entrepreneurship.

The following hypotheses were tested

H1: Attitude has a positive impact on social entrepreneurial intention.

$\mathrm{H} 2$ : Subjective norm has a positive impact on social entrepreneurial intention.

H3: Perceived behavioral control has a positive impact on social entrepreneurial intention.

H4: Contextual element as an entrepreneurial environment and education is significant predictor of social entrepreneurial intention.

\section{Methodology}

The purpose of this study is to find out the intentions of the students towards social entrepreneurship. A sample of 120 students was selected from the group of students in the last year of a bachelor degree program at Ural federal university Russia. A selfadministered questionnaire was developed from the literature with the inclusion of questions that represents the selected variables for this study. The questionnaire was structured in the fill -point Likert scale ranging from Strongly disagree to strongly agree. The different construct of the questionnaire was adopted from the literature such as attitude towards entrepreneurship, perceived behavioral control and entrepreneurial intention were adapted from [30]. The questions for subjective norm construct was adapted from [20] in their research the questions were in the option bad and good ranging from -3 to +3 . The construct for entrepreneurial environment and education, including in the variable subjective norm was adopted from [20] ranging from disagree to Agree. The questionnaire before distribution among students a short pilot test of 25 students was analyzed by Professor of economics and professor of public administration and entrepreneurship to approve the validity. The students were able to fill in the questionnaire in English but were translated into Russian also to make it more understandable and easy for the students. The reliability of the questionnaire was checked to find out a more explainable instrument for selected variables. The reliability of the questionnaire was tested and Cronbach's Alpha for each construct were found above 0.7 for all constructs used in the study. According to [31] the Cronbach's Alpha value of 0.7 or above for reliability and consistency of constructs are acceptable to measure variables. The Cronbach's Alpha values list of each construct is given below in the table (1). A total of 120 questionnaires were distributed among the bachelor students of different specialization study background. The returned questionnaires were 113 among them 6 were not properly filled which were excluded before entering the data into (IBM SPSS version 20).

\section{Results}

Among the 107 participants, 64 were male and 43 were female and were in the average age between 20 to 25 . All participants were full time students except 7 of them who were doing part time jobs. Twenty-two students were from an entrepreneurial family background who were running their businesses of service providing, production or both. 
Basic descriptive statistics were performed to measure the mean and standard deviation of the factors, social entrepreneurial intention, perceived behavioral control, attitude towards entrepreneurship, entrepreneurial environment and education and subjective norm. The average value of attitude towards social entrepreneurship in Table 1, shows moderate results. The highest mean value was found in the response of entrepreneurial environment and education which shows that this variation plays important role in students' intentions towards entrepreneurship. The second highest mean was found of attitude towards social entrepreneurship that means that Russian students are having a positive attitude towards social entrepreneurship.

This table shows the correlation between different independent and dependent variables. All variables were strongly correlated with each other. Perceived behavioral control shows the strongest correlation with social entrepreneurial intention. Comparatively entrepreneurial environment and education shows a strong correlation with other variables. The result shows a strongly significant

Descriptive Statistics of various factors

\begin{tabular}{l|c|c|c|c|c|c|c}
\hline \multicolumn{1}{c|}{ Factors } & $\boldsymbol{N}$ & $\begin{array}{c}\text { Mini- } \\
\text { mum }\end{array}$ & $\begin{array}{c}\text { Maxi- } \\
\text { mum }\end{array}$ & Mean & $\begin{array}{c}\text { Standard } \\
\text { Deviation }\end{array}$ & $\begin{array}{c}\text { N } \\
\text { Items }\end{array}$ & $\begin{array}{c}\text { Cronbach's } \\
\text { Alpha }\end{array}$ \\
\hline $\begin{array}{l}\text { Social } \\
\text { Entrepreneurial } \\
\text { intention. }\end{array}$ & 107 & 1 & 5 & 3.66 & .588 & 6 & 0.85 \\
$\begin{array}{l}\text { Perceived } \\
\text { Behavioral Control. }\end{array}$ & 107 & 1 & 5 & 3.47 & .516 & 6 & 0.74 \\
$\begin{array}{l}\text { Attitude Towards } \\
\text { Entrepreneurship }\end{array}$ & 107 & 1 & 5 & 3.84 & .637 & 5 & 0.82 \\
$\begin{array}{l}\text { Entrepreneurial } \\
\text { Environment and } \\
\text { Education } \\
\text { Subjective Norm }\end{array}$ & 107 & 1 & 5 & 3.87 & .610 & 4 & 0.81 \\
\hline
\end{tabular}

Table 2

Correlation Matrix for various factors

\begin{tabular}{l|c|c|c|c|c}
\hline & SEI & PBC & ATE & EE & SN \\
\hline Social Entrepreneurial intention. & 1 & & & & \\
Perceived Behavioral Control. & $.658^{* *}$ & 1 & & & \\
Attitude Towards Entrepreneurship & $.545^{* *}$ & $.426^{* *}$ & 1 & & \\
Entrepreneurial Environment and Education & $.637^{* *}$ & $.599^{* *}$ & $.626^{* *}$ & 1 & \\
Subjective Norm & $.532 * *$ & $.457^{* *}$ & $.441^{* *}$ & $.433^{* *}$ & 1 \\
\hline
\end{tabular}

**. Correlation is significant at the 0.01 level (2-tailed). $\mathrm{N}=107$ 
correlation of variance with each other to check instability caused by multicollinearity different IDVs variables were regressed separately with other IDV variable in the model. According to [32] If the $\mathrm{R}^{2}$ Value less near to 1 than one variable is collinear with either the highest value of our study was 0.43 which release model from multicollinearity threat (Table 2).

To test the hypothesis in the model multiple regression was used. The values of different variables show significant results. The values $(p<0.05)$ for the support of $\mathrm{H} 1$ attitude have a positive impact on social entrepreneurial intention. Similarly, for the support of other hypotheses $\mathrm{H} 2, \mathrm{H} 3$ and $\mathrm{H} 4(\mathrm{p}<0.05)$ were also significant as shown in table 3 below. There were three main independent variables between them subjective norm was found the most significant in this case. The second highest beta value was found for perceived behavioral control followed by attitude towards entrepreneurship (Table 3).

To check the addition of the value to another variable hierarchical regression was done as used by [21] for checking their proposed hypothesis for the research on students' entrepreneurial intentions. Hierarchical regression allows researchers to check variables based on the theory for the proposed model [33]. To test our H4 we enter first three variables subjective norm, perceived behavioral control and attitude towards entrepreneurship in step 1 , noted the value of $\mathrm{R}^{2} .551$ variances in social entrepreneurial intention changed to $\mathrm{R}^{2}$ on.578. The contextual variable entrepreneurial environment and education were added as a block in the second step and weak but significant changes were found with $(\beta=.232 ; \mathrm{p}=.012)$ as shown in table 4 , below. This shows that with the addition of entrepreneurial education and the environment as contextual predictor add significant value with others towards entrepreneurial intention (Table 4).

\section{Discussion}

The study report confirms the previous work on students' intentions towards entrepreneurship on the basis of the theory of planned behavior (TBP). The results show that predictors of the theory of planned behavior, attitude towards social entrepreneurship, Subjective norm and perceived behavioral control has a significant influence on students' intention towards entrepreneurship. The previous work on students' intentions towards entrepreneurship based on (TBP) predictors provide support to our findings report [22] and [23] used the same predictors for social entrepreneurship intention among students.

Table 3

Regression Analysis: Entrepreneurial intention for Perceived behavioral control, Attitude towards entrepreneurship and Subjective norm

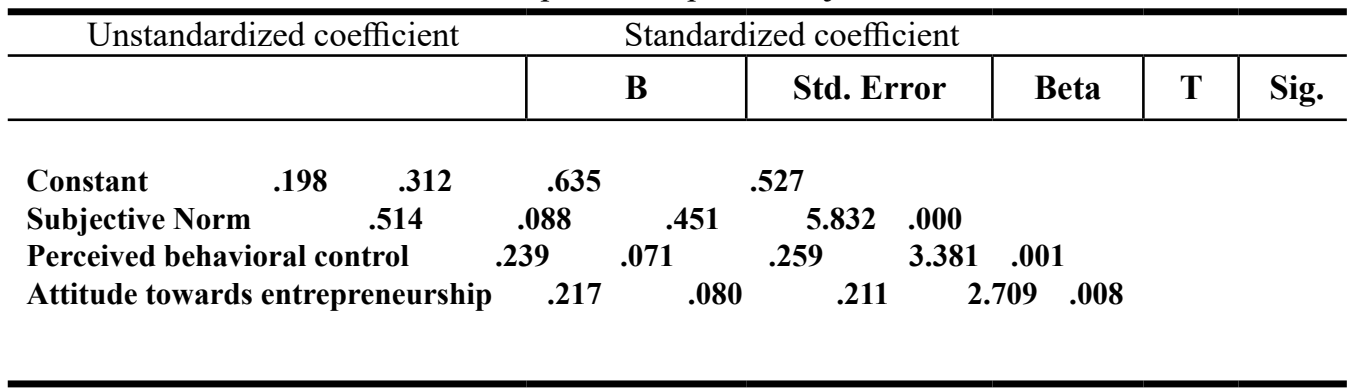

Note: $\mathrm{N}=107 * \mathrm{p}<0.05,{ }^{*} \mathrm{p}<0.01$, Adjusted $\mathrm{R}^{2}=.551, \mathrm{~F}$-Statistics $=42.10$, Significant at 0.000 . 
The other researchers used the same theory for predicting the commercial entrepreneurship intention [3] and [29]. Some of them used the predictors to prove the theory of (TPB) to be a suitable tool for measuring entrepreneurship [21] tested this on students in Africa and got significant results.

In our study, we found that Russian students have a positive attitude towards social entrepreneurship; perceived behavioral control were also found significant the most significant factor was subjective norm. Here in support we can say that starting social enterprise is a behavior connected somehow with people, that's why this factor shows the most significant value. Explaining this behavior [34] says that professional social entrepreneurs first evaluate that society or community will accept or welcome their idea. This can also be the possibility that subjective norm is the combination of not only the friends, family and colleagues, but the environment and the community of the university where students spend the important part of the day.

According to Pache and Chowdhury, in social entrepreneurship, education develops the students' mindset in different angles. It increases the ability of the students to investigate the problems and evaluate those problems. Entrepreneurship education also develops the students' ability to combine different logics to find the solution to the problems [2]. In concluding remarks on conducting research on social entrepreneurship awareness of students based on (TPB) [23] suggested that for entrepreneurial action a person needs proper information, opinion, encouragement and particularly the ability and knowledge to do it. These things are mostly the part of entrepreneurial environment and education.

Social entrepreneurship is quite difficult to define simply but the skills which are helpful in solving a social or commercial problem in an innovative way is possible. These skills can possibly be acquired during studies when opportunities are provided by offering special courses. Education and training should help students to acquire work in teams, communication skills, critical and problemsolving skills with these skills they can identify opportunities and can handle different situations [28].

Based on this importance of the factors which we have revealed through this study there are some suggestions to be implemented in the education sector.

Table 4

Hierarchical regression analysis of dependent variables with contextual variable

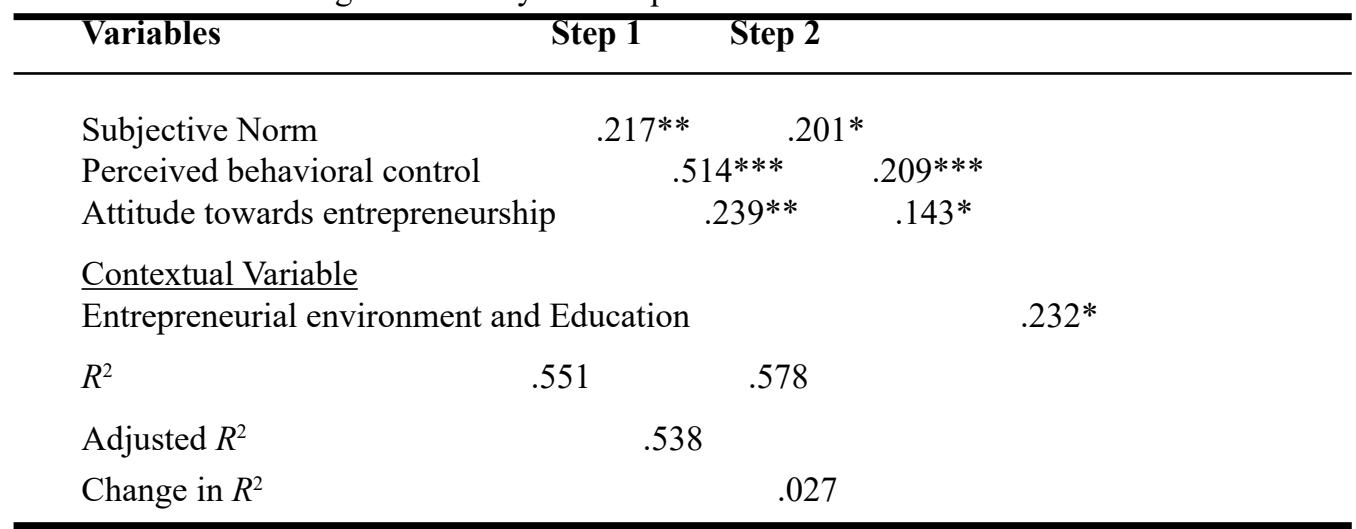

Note: Note: $\mathrm{N}=107 * \mathrm{p}<0.05, * * \mathrm{p}<0.01, * * *<.001$, Significant at 0.012 . 
Firstly, the importance of entrepreneurship education, specifically in social entrepreneurship not only limited to the students of certain academic background. It is needed at all levels of education and specialization due to its importance in current advance and technological era.

Secondly, there is a need for attitudinal change through increase public awareness and promotion of social entrepreneurship. This will bring possible innovative and creative solutions to the society's problems.

Universities should incorporate extra curricula activities on social entrepreneurship regardless of compulsory courses on social entrepreneurship. This may help in changing the perception of students' attitude towards entrepreneurship.

The study was conducted and analyzed on the basis of a convenient sample in the Institute of Public Administration and Entrepreneurship at Ural Federal University. Therefore, we are not going to make generalizations of the world biggest country on the basis of this study.

\section{Conclusion}

The purpose of the study was to investigate the intention of the students towards social entrepreneurship. After evaluation of the response from the students towards social entrepreneurship intention. The research conclude that students consider social entrepreneurship as a preferable means to enhance their career. Intention towards a certain behavior is not the actual behavior the decision of the students can be change with time. The study also observed that academic support and entrepreneurial environment enhance the intentions of students towards social entrepreneurship. The overall results of this study were quite impressive. The high positive response towards social entrepreneurship can be attributed to the students' acquisition of social entrepreneurship training. Entrepreneurship is a risky phenomenon at young ages, but to tell and train students about alternate career choice is necessary. To increase the intention of the students towards social entrepreneurship their involvement in social entrepreneurial activities may play an important role. The students in their young ages, especially in the last year of study want to do something innovative and creative for the betterment of their societies. They enthusiastically want to solve social problems through social enterprises. In order to attract students' attention towards social entrepreneurship, excursion is necessary to be introduced to the concept of social entrepreneurship during their studies. The initiators of this excursion include policy makers and education authorities in order to give importance to social entrepreneurship and make it part of all levels of education from secondary school to university. The study as a drop contribution to the ocean of entrepreneurship literature. Further research on increasing the sample size and comparison of the cities and genders respondents will make the contribution stronger.

\section{Acknowledgment}

The article is prepared in accordance with the 2018 FANO State Task to the Institute of Economy, Urals Chapter, Russian Academy of Sciences, Yekaterinburg, Russia. 


\section{References}

1. Ana, M., Murdith, M. (2006). Social entrepreneurship: A critical review of the concept. Journal of World Business, Vol. 41, Issue 1, 56-65.

2. Cromie, S. (2000). Assessing entrepreneurial inclinations: Some approaches and empirical evidence. European Journal of Work and Organizational Psychology, Vol. 9, No. 1, 7-30.

3. Gulruh, G., Sinem, A. (2008). Entrepreneurial intentions of young Turkish public and Turkey. Journal of Global Strategic Management, Vol. 4, Issue 1, 47-56.

4. Tkashev, A., Kolvereid, L. (1999). Selfemployment intention among Russian students. Journal of Entrepreneuship and Regional Development, Vol. 11, Issue 3, 269-280. Available at: https:// www.researchgate.net/profile/Lars Kolvereid/publication/261644309_ Self-Employment_Intentions_among _ Russian Students.

5. Moskovskaya, A. (2015). Time for New Opportunities 15-20' Forum of entrepreneurs. Available at: https:// socentr.hse.ru/en/news/150383430.html.

6. Auerswald, P. (2009). Creating social value. Stanford Social Innovation Review, Spring, 50-55.

7. Hibbert, S.A., Hogg, G., Quinn, T. (2005). Social entrepreneur ship: understanding consumer motives for buying The Big Issue. Journal of Consumer Behaviour, Vol. 4, No. 3, 159-172.

8. Durieux, M.B., Stebbins, R.A. (2010). Social entrepreneurship for dummies. Hoboken, Wiley Publishing.

9. Alvord, S.H., Brown, L.D., Letts, C.W. (2004). Social entrepreneurship and societal transformation an exploratory study. The Journal of Applied
Behavioral Science, Vol. 40, No. 3, 260-282.

10. Social Entrepreneurship (2006). Edited by J. Mair, J. Robinson, K. Hockerts. New York, Palgrave Macmillan, 280.

11. Thompson, J.L. (2002). The world of Social entrepreneur. The International Journal of Public Sector Management, Vol. 15, No. 5, 412-431.

12. Martínez, D., Ginés-Mora, J., Vila, L. (2007). Entrepreneurs, the selfemployed and employees amongst young European higher education graduates. European Journal of Education, Vol. 42, No. 1, 99-117.

13. Ajzen, I. (1988). Attitudes, Personality, and Behaviour. New York, McGrawHill International.

14. Ajzen, I. (1991). The theory of planned Behaviour. Organizational Behaviour and Human Decision Processes, Vol. 50, No. 2, 179-211.

15. Krueger, N.F. Jr., Reilly, M.D., Carsrud, A.L. (2000). Competing models of entrepreneurial intentions. Journal of Business Venturing, Vol. 15, No. 5-6, 411-432.

16. Rae, D. (2010). Universities and enterprise education: responding to the challenges of a new era. Journal of Small Business and Enterprise Development, Vol. 17, No. 4, 591-606.

17. Brock, D.D., Kim, M. (2011). Social entrepreneurship education resource handbook. Ashoka U, the University Division of Ashoka: Innovators for the Public.

18. Bornstein, D. (2004). How to change the world: social entrepreneurs and the power of new ideas. New York, Oxford University Press.

19. Sherman, S. (2011). Teaching the key skills of successful social entrepreneurs. Stanford Social Innovation Review. 
Available at: https://ssir.org/articles/ entry/teaching_the_key_skills_of_ successful_social_entrepreneurs.

20. Autio, E., Keeley, R.H., Klofsten, M., Parker, G.G.C., Hay, M. (2001). Entrepreneurial Intent among Students in Scandinavia and in the USA. Enterprise and Innovation Management Studies, Vol. 2, No. 2, 145-160.

21. Gird, A., Bagraim, G. (2008). The theory of plain behavior as a predictor of entrepreneurial intent among finalyear university students. South African Journal of Psychology, Vol. 38, No. 4, 711-724.

22. Salamzadeh,A.,Azimi, M.A., Kirby, D.A. (2013). Social entrepreneurship education in higher education: insights from a developing country. International Journal of Entrepreneurship and Small Business, Vol. 20, No. 1, 17-34.

23. Kirby, D.A., Ibrahim, N. (2011). The case for (social) entrepreneurship education in Egyptian universities. Education + Training, Vol. 53, No. 5, 403-415.

24. Sarada, C., Satyanarayana, R. (2017). Intentions towards social entrepreneurship among university students in India. International Journal of Research - Granthaalayah, Vol. 5, No. 6, 406-413.

25. Krueger, N.F. (2009). Entrepreneurial intentions are dead: long live entrepreneurial intentions. In Understanding the Entrepreneurial Mind - Opening the Black Box. Edited by A.L. Carsrud, M. Brännback. Dordrecht, Springer.

26. Bird, B. (1988). Implementing entrepreneurial ideas: The case for intention. Academy of Management Review, Vol. 13, No. 3, 442-453.

27. Krueger, N.F., Carsrud, A.L. (1993). Entrepreneurial intentions: applying the theory of planned behaviour. Entrepreneurship \& Regional Development: An International Journal, Vol. 5, No. 4, 315-330.

28. Veciana, J.M., Aponte, M., Urbano, D. (2005). University students' attitudes towards entrepreneurship: A two countries comparison. The International Entrepreneurship and Management Journal, Vol. 1, No. 2, 165-182.

29. Arifatul, H.M.A., Zainol, B., Zakiyah, S., Adura, A. (2010). Predicting entrepreneurship intention among Malay university accounting students in Malaysia. Unitar E-Journal, Vol. 6, No. 1, 1-10.

30. Liñán, F., Chen, Y.W. (2009). Development and Cross-Cultural application of a specific instrument to measure entrepreneurial intentions. Entrepreneurship Theory and Practice, Vol. 33, No. 3, 593-617.

31. Hair, J.F., Black, W.C., Babin, B.J., Anderson, R.E. (2010). Multivariate data analysis. A global perspective. 7th edition. New Jersey, Prentice Hall.

32. Allison, P.D. (1999). Multiple Regression: A primer. Thousand Oaks, CA, Pine Forge Press.

33. Tabachnick, B.G., Fidell, L.S. (2007). Using Multivariate Statistics. 5th Edition. Boston, Pearson.

34. Krueger, N.F., Brazeal, D.V. (1994). Entrepreneurial potential and potential entrepreneurs. Entrepreneurship Theory and Practice, Vol. 18, No. 1, 91-104. 
С.Н. Полбицын

Уральский федеральный университет имени первого Президента России Б.Н. Ельцина, Иг. Екатеринбург, Россия

Абидулла

Уральский федеральный университет имени первого Президента России Б.Н. Ельциина, 2. Екатеринбург, Россия

\title{
ФОРМИРОВАНИЕ ИНТЕНЦИЙ СТУДЕНТОВ РОССИЙСКОГО УНИВЕРСИТЕТА В СФЕРЕ СОЦИАЛЬНОГО ПРЕДПРИНИМАТЕЛЬСТВА
}

\begin{abstract}
Аннотация. В настоящее время социальное предпринимательство является актуальной и перспективной темой исследований. Социальное предпринимательство требует развития особых форм знания, умений и навыков. Вовлечь молодежь в социальное предпринимательство и предоставить им возможность использовать свои знания, навыки и способности для решения проблем реального мира - это задача современного общества. В предлагаемой статье изучаются интенции студентов в области социального предпринимательства. Исследование направление на анализ интенций как важного предиктора поведенческой модели социального предпринимательства. В статье выдвигается гипотеза значимости факторов, оказывающих влияние на предпринимательские интенции студентов. Авторы утверждают, что намерение стать социальным предпринимателем определяется в большей степени субъективными, а не объективными факторами, поэтому деятельность университетов по формированию предпринимательских интенций должна быть направлена на развитие особой поведенческой модели.

В статье объясняются факторы, обусловливающие стремление студентов к социальному предпринимательству. Доказательство гипотезы строится на основе данных полученных в результате опроса студентов. Была использована случайная выборка из 107 студентов. Интерпретация и анализ корреляции и множественной регрессии в статье основывались на использовании «Статистического пакета для социальных наук» (SPSS, версия 20). В качестве теоретико-методологической основы исследования была использована теория спланированного поведения. Наряду с такими переменными отношения к предпринимательству как субъективная норма и воспринимаемый поведенческий контроль, было показано значимое влияние предпринимательской среды и образования: последние оказывают сильное влияние на интенции и инициативу студентов в социальном предпринимательстве. Выводы свидетельствуют о том, что государству необходимо уделять больше внимания предпринимательскому образованию, вовлечению молодежи в социальное предпринимательство.
\end{abstract}

Ключевые слова: интенции к предпринимательству; восприятие поведенческого контроля; субъективная норма; предпринимательское намерение; предпринимательская среда и образование. 


\section{Список использованных источников}

1. Ana M., Murdith M. Social entrepreneurship: A critical review of the concept // Journal of World Business. 2006. Vol. 41, Issue 1. P. 56-65.

2. Cromie S. Assessing entrepreneurial inclinations: Some approaches and empirical evidence // European Journal of Work and Organizational Psychology. 2000. Vol. 9, No. 1. P. 7-30.

3. Gulruh G., Sinem A. Entrepreneurial intentions of young Turkish public and Turkey // Journal of Global Strategic Management. 2008. Vol. 4, Issue 1. P. 47-56.

4. Tkashev A., Kolvereid L. (1999). Self-employment intention among Russian students // Journal of Entrepreneuship and Regional Development. 1999. Vol. 11, Issue 3. P. 269-280. Режим доступа: https:// www.researchgate.net/profile/Lars Kolvereid/publication/261644309 Self-Employment_Intentions_among_ Russian_Students.

5. Moskovskaya A. Time for New Opportunities 15-20' Forum of entrepreneurs. [Электронный ресурс]. Режим доступа: https://socentr.hse.ru/ en/news/150383430.html.

6. Auerswald P. Creating social value // Stanford Social Innovation Review. 2009. Spring. P. 50-55.

7. Hibbert S.A., Hogg G., Quinn T. Social entrepreneur ship: understanding consumer motives for buying The Big Issue // Journal of Consumer Behaviour. 2005. Vol. 4, No. 3. P. 159-172.

8. Durieux M.B., Stebbins R.A. Social entrepreneurship for dummies. Hoboken: Wiley Publishing, 2010.

9. Alvord S.H., Brown L.D., Letts C.W. Social entrepreneurship and societal transformation an exploratory study // The Journal of Applied Behavioral Science. 2004. Vol. 40, No. 3. P. 260-282.

10. Social Entrepreneurship / Ed. by J. Mair, J. Robinson, K. Hockerts. New York: Palgrave Macmillan, 2006. $280 \mathrm{p}$.

11. Thompson J.L. The world of Social entrepreneur // The International Journal of Public Sector Management. 2002. Vol. 15, No. 5. P. 412-431.

12. Martínez D., Ginés-Mora J., Vila L. Entrepreneurs, the self-employed and employees amongst young European higher education graduates // European Journal of Education. 2007. Vol. 42, No. 1. P. 99-117.

13. Ajzen I. Attitudes, Personality, and Behaviour. New York: McGraw-Hill International, 1988.

14. Ajzen I. The theory of planned Behaviour // Organizational Behaviour and Human Decision Processes. 1991. Vol. 50, No. 2. P. 179-211.

15. Krueger N.F. Jr., Reilly M.D., Carsrud A.L. Competing models of entrepreneurial intentions // Journal of Business Venturing. 2000. Vol. 15, No. 5-6. P. 411-432.

16. Rae D. Universities and enterprise education: responding to the challenges of a new era // Journal of Small Business and Enterprise Development. 2010. Vol. 17, No. 4. P. 591-606.

17. Brock D.D., Kim M. Social entrepreneurship education resource handbook. Ashoka U, the University Division of Ashoka: Innovators for the Public, 2011.

18. Bornstein D. How to change the world: social entrepreneurs and the power of new ideas. New York: Oxford University Press, 2004. 
19. Sherman S. Teaching the key skills of successful social entrepreneurs. Stanford Social Innovation Review. 2011 [Электронный pecypc]. Peжим доступа: https://ssir.org/articles/ entry/teaching_the_key_skills_of_ successful_social_entrepreneurs.

20. Autio E., Keeley R.H., Klofsten M., Parker G.G.C., Hay M. Entrepreneurial Intent among Students in Scandinavia and in the USA // Enterprise and Innovation Management Studies. 2001. Vol. 2, No. 2. P. 145-160.

21. Gird A., Bagraim G. The theory of plain behavior as a predictor of entrepreneurial intent among final-year university students // South African Journal of Psychology. 2008. Vol. 38, No. 4. P. 711-724.

22. Salamzadeh A., Azimi M.A., Kirby D.A. Social entrepreneurship education in higher education: insights from a developing country // International Journal of Entrepreneurship and Small Business. 2013. Vol. 20, No. 1. P. 17-34.

23. Kirby D.A., Ibrahim N. The case for (social) entrepreneurship education in Egyptian universities // Education + Training. 2011. Vol. 53, No. 5. P. 403-415.

24. Sarada C., Satyanarayana R. Intentions towards social entrepreneurship among university students in India // International Journal of Research Granthaalayah. 2017. Vol. 5, No. 6. P. 406-413.

25. Krueger N.F. Entrepreneurial intentions are dead: long live entrepreneurial intentions // In Understanding the Entrepreneurial Mind - Opening the Black Box / ed. by A.L. Carsrud, M. Brännback. Dordrecht: Springer, 2009.
26. Bird B. Implementing entrepreneurial ideas: The case for intention // Academy of Management Review. 1988. Vol. 13, No. 3. P. 442-453.

27. Krueger N.F., Carsrud A.L. Entrepreneurial intentions: applying the theory of planned behaviour // Entrepreneurship \& Regional Development: An International Journal. 1993. Vol. 5, No. 4. P. 315-330.

28. Veciana J.M., Aponte M., Urbano D. University students' attitudes towards entrepreneurship: A two countries comparison // The International Entrepreneurship and Management Journal. 2005. Vol. 1, No. 2. P. 165-182.

29. Arifatul H.M.A., Zainol B., Zakiyah S., Adura A. Predicting entrepreneurship intention among Malay university accounting students in Malaysia // Unitar E-Journal. 2010. Vol. 6, No. 1. P. $1-10$.

30. Liñán F., Chen Y.W. Development and Cross-Cultural application of a specific instrument to measure entrepreneurial intentions // Entrepreneurship Theory and Practice. 2009. Vol. 33, No. 3. P. 593-617.

31. Hair J.F., Black W.C., Babin B.J., Anderson R.E. Multivariate data analysis. A global perspective. 7th edition. New Jersey: Prentice Hall, 2010.

32. Allison P.D. Multiple Regression: A primer. Thousand Oaks, CA: Pine Forge Press, 1999.

33. Tabachnick B.G., Fidell L.S. (2007) Using Multivariate Statistics. 5th Edition. Boston: Pearson, 2007

34. Krueger N.F., Brazeal D.V. Entrepreneurial potential and potential entrepreneurs // Entrepreneurship Theory and Practice. 1994. Vol. 18, No. 1. P. 91-104. 


\section{Информация об авторах}

Полбицын Сергей Николаевич - доктор экономических наук, доцент, профессор кафедры региональной экономики, инновационного предпринимательства и безопасности Уральского федерального университета имени первого Президента России Б.Н. Ельцина, старший научный сотрудник Института экономики Уральского отделения РАН г. Екатеринбург, Россия (620002, г. Екатеринбург, ул. Мира, 19); e-mail: s.n.polbitsyn@urfu.ru.

Абидулла - аспирант кафедры региональной экономики, инновационного предпринимательства и безопасности Уральского федерального университета имени первого Президента России Б.Н. Ельцина, г. Екатеринбург, Россия (620002, г. Екатеринбург, ул. Мира, 19); e-mail: abidullah856@gmail.com.

Для цитирования: Полбицын С.Н., Абидулла. Формирование интенций студентов российского университета в сфере социального предпринимательства // Вестник УрФУ. Серия экономика и управление. 2018. Т. 17, № 3. С. 554-568. DOI: 10.15826/vestnik.2018.17.3.024.

For Citation: Polbitsyn S.N., Abidullah. Russian University Students Intentions Towards Social Entrepreneurship. Bulletin of Ural Federal University. Series Economics and Management, 2018, Vol. 17, No. 3, 554-568. DOI: 10.15826/vestnik.2018.17.3.024.

Информация о статье: дата поступления 02 февраля 2018 г.; дата принятия к печати 18 апреля 2018 г.

Article Info: Received February 02, 2018; Accepted April 18, 2018. 